\title{
The effects of golimumab treatment on systolic and diastolic left ventricular function in ankylosing spondylitis
}

This article was published in the following Dove Press journal:

Biologics:Targets and Therapy

\author{
SC Heslinga ${ }^{1,2}$ \\ TC Konings ${ }^{3}$ \\ IE van der Horst- \\ Bruinsma ${ }^{1,2}$ \\ O Kamp ${ }^{3}$ \\ VP van $\mathrm{Halm}^{3,4}$ \\ HACM de Bruin-Bon ${ }^{4}$ \\ MJ Peters ${ }^{5}$ \\ MT Nurmohamed ${ }^{1,2}$ \\ 'Department of Rheumatology, \\ Amsterdam Rheumatology and \\ Immunology Center, Reade, \\ Amsterdam, The Netherlands; \\ ${ }^{2}$ Department of Rheumatology, \\ Amsterdam Rheumatology and \\ Immunology Center, VU University \\ Medical Center, Amsterdam, The \\ Netherlands; ${ }^{3}$ Department of \\ Cardiology, VU University Medical \\ Center, Amsterdam, The Netherlands; \\ ${ }^{4}$ Department of Cardiology, Academic \\ Medical Center, Amsterdam, The \\ Netherlands; ${ }^{5}$ Department of Internal \\ Medicine, VU University Medical \\ Center, Amsterdam, The Netherlands
}

Correspondence: SC Heslinga

Department of Rheumatology,

Amsterdam Rheumatology and

Immunology Center, Reade, Jan van

Breemenstraat 2, 1056 AB, Amsterdam,

The Netherlands

$\mathrm{Tel}+3$ I 20242 II 00

Email s.heslinga@reade.nl
Background: Diastolic left ventricular (LV) dysfunction appears more prevalent in ankylosing spondylitis (AS). The effects of tumor necrosis factor alpha (TNF- $\alpha$ ) blocking therapy, a strong and effective anti-inflammatory drug, on diastolic LV function in AS are unknown. The objective of the study was to find the effects of 1-year treatment with golimumab $50 \mathrm{mg}$ subcutaneously once per month on systolic and diastolic LV dysfunction in AS patients.

Methods: Forty consecutive AS patients were treated with TNF- $\alpha$ blocking therapy for 1 year. Transthoracic echocardiography was performed in all patients at baseline and after 1 year of treatment.

Results: Diastolic LV function improved after treatment in four out of six (67\%) AS patients who completed follow-up $(P=0.125)$, and did not develop or worsen in any of the other patients. Treatment with TNF- $\alpha$ blocking therapy had no effect on systolic LV function.

Conclusion: These findings give support to the hypothesis that diastolic LV dysfunction improves during treatment with TNF- $\alpha$ blocking therapy.

Keywords: ankylosing spondylitis, cardiovascular disease, anti-TNF

\section{Introduction}

Ankylosing spondylitis (AS) is a chronic inflammatory rheumatic disease that affects the spinal column causing pain and decreased spinal flexibility. ${ }^{1,2}$ Extra-spinal manifestations including cardiac pathology are common in AS. ${ }^{3-5}$ The cardiac pathology linked to AS includes valvular dysfunction, in particular of the aortic valve, conduction disorders and heart failure (HF). ${ }^{3,6-9}$

It is conceivable that these cardiac abnormalities originate due to the systemic inflammatory process inherent to AS, as inflammation may affect the aortic root, aortic and mitral valve cups, the atrioventricular node and the proximal septum. ${ }^{10,11}$ Also, inflammation accelerates the process of atherosclerosis, increasing the chance of developing ischemic heart disease and HF. ${ }^{12-14}$ Finally, inflammation might affect the myocardium and endocardium itself, leading to an abnormal filling pattern termed diastolic left ventricular (LV) dysfunction. ${ }^{15}$ Diastolic LV dysfunction is caused by impaired relaxation of the left ventricle and may eventually lead to HF with preserved ejection fraction. ${ }^{16}$ Failing pump function of the heart is termed systolic LV dysfunction and may lead to HF with reduced ejection fraction. ${ }^{16}$

Recently, we performed a review that suggested a higher prevalence of diastolic LV dysfunction in AS patients, an important precursor to chronic HF that may contribute to the enhanced morbidity and mortality in $\mathrm{AS} .{ }^{8}$ Considering this, in this study we 
investigated the precise magnitude of LV dysfunction, particularly diastolic LF dysfunction, in AS patients and we examined the effect of tumor necrosis factor alpha (TNF- $\alpha$ ) blocking therapy on LV function during a treatment period of 1 year.

\section{Methods}

\section{Study population}

Consecutive AS patients were included at the rheumatology departments of the VU University Medical Center (VUmc) and Reade, Amsterdam, The Netherlands, from November 2012 to May 2014. All patients fulfilled the 1984 Modified New York criteria for AS. ${ }^{17}$ Patients were included when they were eligible for treatment with TNF- $\alpha$ blocking therapy and were treated for 1 year with golimumab (Simponi ${ }^{\circledR}$; Merck Sharp \& Dohme B.V., Haarlem, The Netherlands) $50 \mathrm{mg}$ subcutaneously once a month. Switching to another TNF- $\alpha$ blocker during the study was allowed. Cardiac function was assessed with transthoracic echocardiography (TTE) at baseline and after 1 year of treatment. Approval was obtained from the local ethics committee (Ethics Committee of the Slotervaart Hospital and Reade, Amsterdam, The Netherlands) and all participating patients gave written informed consent.

\section{Patient and disease characteristics}

Medical history included AS history, medication use, hypertension, diabetes mellitus type 2 and CV events. Patients with a history of $\mathrm{CV}$ events were subsequently excluded. Physical examination included height, weight and blood pressure measurements. Body mass index was calculated. Hypertension was defined as present if a patient was treated with antihypertensive medication or had an indication for treatment. Blood sample measurements included standard hematological assessment, C-reactive protein (CRP) and erythrocyte sedimentation rate (ESR). Disease activity was measured with the Bath Ankylosing Spondylitis Disease Activity Index (BASDAI), Bath Ankylosing Spondylitis Functional Index (BASFI) and the Ankylosing Spondylitis Disease Activity Score - CRP (ASDAS).

\section{Transthoracic echocardiography}

TTE was performed by experienced echo technicians at the VUmc. To exclude inter-observer variability, all recordings of echocardiography data from both AS patients and controls were stored digitally and were afterwards analyzed offline by a single investigator (T.K.). TTE was performed according to the following protocol based on the guidelines provided by American Society of Echocardiography. ${ }^{18}$ Evaluation of cardiac function consisted of $2 \mathrm{D}$, spectral and color flow
Doppler recordings. The $2 \mathrm{D}$ recordings were performed in parasternal long- and short-axis views, and apical four-, threeand two-chamber views. Left atrial and ventricular diastolic and systolic diameters, posterior wall thicknesses (PWT) and interventricular septum thicknesses (IVS) were measured during systole and diastole by 2D imaging. Left ventricular mass was calculated with the following formula: 0.8 (1.04) (end diastolic diameter [EDD]+IVS+PWT) 3-(EDD3)+0.6 (in grams). The relative wall thickness was calculated as following: (IVS+PWT)/EDD. Left ventricular systolic and diastolic volumes and ejection fraction (EF) were calculated from the apical four chamber view using 3D echocardiography or modified Simpson's method. ${ }^{18}$ Left atrial volume was measured using modified biplane Simpson's rule. Aortic and mitral valve function was evaluated using color Doppler flow. Pulsed-Doppler spectral recordings of the mitral inflow were obtained with the sample volume placed at the tips of the mitral leaflets. From the transmitral pulsed-Doppler recordings, peak $\mathrm{E}$ and $\mathrm{A}$ velocities, the $\mathrm{E} / \mathrm{A}$ ratio and the E wave deceleration times (DT) were obtained. Pulse wave tissue Doppler imaging was performed in the apical views to acquire mitral annular velocities. The sample volume was positioned at, or within $1 \mathrm{~cm}$ of the septal (e' sept) and lateral (e' lat) insertion sites of the mitral leaflets.

\section{Definitions}

Systolic LV dysfunction was defined as an EF <50\%. Expert opinion defined the presence of systolic LV dysfunction if the EF could not be determined due to image quality or other. Diastolic LV dysfunction was graded into three categories: mild (grade I), pseudonormal (grade II) and restrictive (grade III), using criteria based on the recommendations by Nagueh et al. ${ }^{19}$ Diastolic LV dysfunction was present when at least two out of three measurements (ie, e' sept, e' lat, left atrial volume) were abnormal. The specific grade of diastolic LV dysfunction (normal, mild, pseudonormal or restrictive) was defined when at least two of the three measurements (ie, E/A ratio, DT, E/e' ratio) met that specific grade. Valvular function and aortic diameters were evaluated according to the most recent echocardiographic guidelines. ${ }^{18,20}$

\section{Statistical analysis}

For data analysis, SPSS Version 19.0 (IBM Corp., Armonk, NY, USA) was used. Demographic and disease characteristics were summarized using descriptive statistics. Distribution of data was analyzed with histograms. Values are expressed as mean $\pm \mathrm{SD}$, median (interquartile range) or numbers (percentages, \%) where appropriate. Independent samples 
$t$-tests were used for comparisons of normally distributed continuous variables and Mann-Whitney $U$-test for nonnormally distributed continuous variables. Fisher's exact test was performed on dichotomous variables. Echocardiographic data of all patients completing the follow-up at 1 year were analyzed using the paired samples $t$-test, Wilcoxon signedrank test or McNemar test, where appropriate. A level of $P<0.05$ was considered statistically significant.

\section{Results}

\section{Patient, control and disease characteristics}

In total, 47 consecutive AS patients were included. Three patients refused echocardiography, and four patients had a history of CV events (myocardial infarction $n=2$, cerebrovascular accident $n=2$ ) and were subsequently excluded (Figure 1). Baseline data are shown in Table 1. Of all AS patients, 33 (83\%) were HLA-B27 positive. Before initiation of TNF- $\alpha$ blocking therapy, the mean BASDAI score was 5.6 \pm 1.7 and the mean ASDAS score was 3.2 \pm 1.2 . Six $(15 \%)$ AS patients had a history of hypertension compared to none in the control group $(P=0.011)$.

\section{Baseline echocardiography}

In total, 13 (33\%) AS patients had cardiac pathology (ie, one or more of the following: systolic and/or diastolic LV dysfunction, aortic valve dysfunction and/or aortic dilatation; one AS patient had two disorders), see Table 2.

Nine (23\%) AS patients had diastolic LV dysfunction at baseline. The mean age of patients with diastolic LV dysfunction was $52.2 \pm 7.2$ years compared to $38.7 \pm 9.8$ years in patients with a normal diastolic LV function $(P<0.001)$, and the prevalence of hypertension was $44 \%$ in patients with diastolic LV dysfunction compared to $6 \%$ in patients with a normal diastolic LV function $(P=0.005)$ (Table 3$)$. Levels of CRP: 4 (1-12) mg/L vs 9 (6-20) mg/L, and ESR: 6 (5-25) $\mathrm{mm} / \mathrm{h}$ vs $14(6-46) \mathrm{mm} / \mathrm{h}$ were higher in the group of patients with diastolic LV dysfunction, however, these differences did not reach statistical significance.

\section{Follow-up echocardiography after I year of treatment}

Results are shown in Table 4. Of all 40 patients, 31 (78\%) completed the study. Two patients switched to adalimumab during follow-up up due to treatment failure. The reasons for dropping out of the study were treatment failure $(n=5)$ or loss to follow-up $(n=4)$. There were no baseline differences between these two groups regarding age and inflammation levels, except that the BASDAI ( $6.8 \pm 1.6$ vs $5.2 \pm 1.6, P=0.016)$ and BASFI $(6.4 \pm 2.8$ vs $4.0 \pm 2.0, P=0.016)$ scores were significantly higher in the group of dropouts compared to those who completed the study. Treatment with TNF- $\alpha$ blocking therapy resulted in a significant decrease in inflammatory and disease activity, with median CRP levels decreasing from $5.0(2.0-12.0) \mathrm{mg} / \mathrm{L}$ to $2.0(1.9-3.2) \mathrm{mg} / \mathrm{L}(P<0.001)$, mean BASDAI decreasing from $5.2 \pm 1.6$ to $3.7 \pm 2.3(P=0.001)$ and mean ASDAS decreasing from $3.1 \pm 1.2$ to $2.0 \pm 1.0(P<0.001)$.

In four out of six AS patients, diastolic LV function improved during treatment $(P=0.125)$, see Figure 2 . In three patients, diastolic LV dysfunction grade I improved to normal function, and one patient with diastolic LV dysfunction grade II had a normal function after 12 months. In none of the other patients, the grade of diastolic LV function worsened, and no new cases of diastolic LV dysfunction were found. Treatment with TNF- $\alpha$ blocking therapy had no effect on LV mass, left atrial volume or systolic LV function.

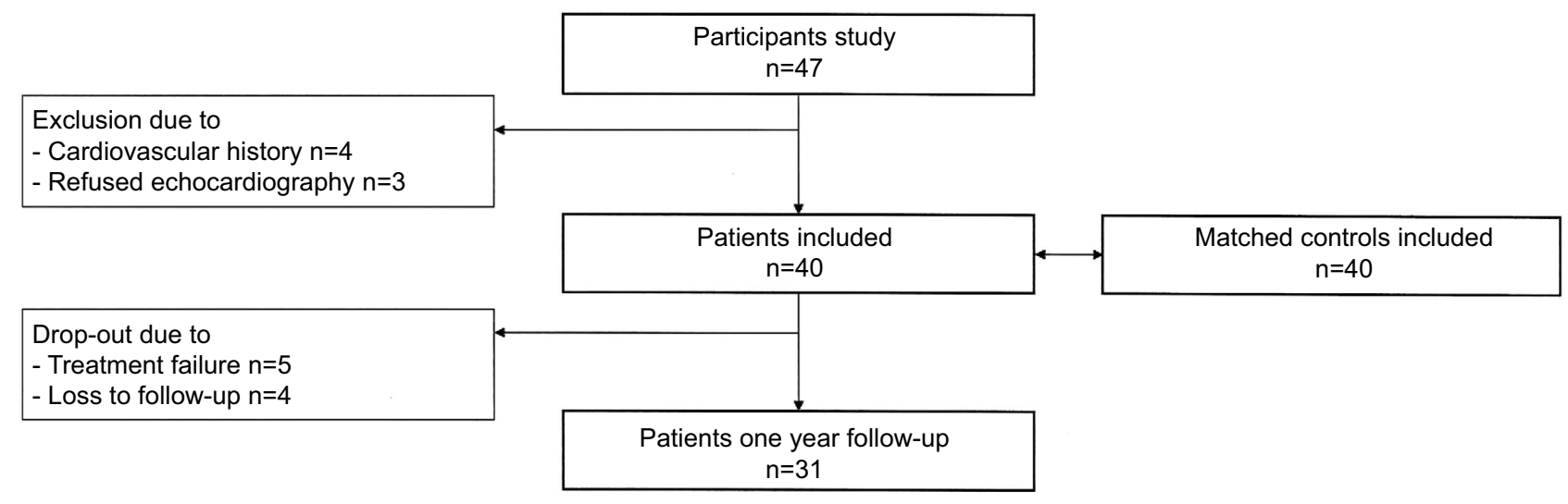

Figure I Flowchart of included patients. 
Table I Baseline characteristics

\begin{tabular}{|c|c|}
\hline Variables & \\
\hline Age, years (mean $\pm S D)$ & $41.8 \pm 10.8$ \\
\hline Gender, male n (\%) & $27(68)$ \\
\hline Body mass index, $\mathrm{kg} / \mathrm{m}^{2}$ (median, range) & $24.4(21.9-28.0)$ \\
\hline Hypertension n (\%) & $6(15)$ \\
\hline Diabetes mellitus type $2 \mathrm{n}(\%)$ & I (3) \\
\hline \multicolumn{2}{|l|}{ Disease characteristics } \\
\hline Years since disease onset (median, range) & $16(9-24)$ \\
\hline Years since diagnosis (median, range) & $8(2-16)$ \\
\hline HLA-B27 positive $n(\%)$ & $33(83)$ \\
\hline Systolic blood pressure, $\mathrm{mmHg}($ mean $\pm \mathrm{SD})$ & $126 \pm 13$ \\
\hline Diastolic blood pressure, $\mathrm{mmHg}($ mean $\pm \mathrm{SD})$ & $8 I \pm 7$ \\
\hline $\mathrm{ESR}, \mathrm{mm} / \mathrm{h}$ (median, range) & $10(6-22)$ \\
\hline CRP, mg/L (median, range) & $4(1-12)$ \\
\hline BASDAI (mean \pm SD) & $5.6 \pm 1.7$ \\
\hline BASFI (mean \pm SD) & $4.5 \pm 2.4$ \\
\hline ASDAS (mean \pm SD) & $3.2 \pm 1.2$ \\
\hline Prior anti TNF- $\alpha$ medication use $\mathrm{n}(\%)$ & $22(55)$ \\
\hline Current NSAIDs use $\mathrm{n}(\%)$ & $33(83)$ \\
\hline $\begin{array}{l}\text { Years of prior anti TNF- } \alpha \text { medication use } \\
\text { (median, range) }\end{array}$ & $0.3(0.0-4.0)$ \\
\hline \multicolumn{2}{|l|}{ Echocardiography } \\
\hline Cardiac abnormality $\mathrm{n}(\%)^{*}$ & $13(33)$ \\
\hline Systolic LV dysfunction $\mathrm{n}(\%)$ & $0(0)$ \\
\hline Diastolic LV dysfunction $\mathrm{n}(\%)$ & $9(23)$ \\
\hline Grade $1 / I / I / I I I$ n (\%) & $7(18) / 2(5) / 0(0)$ \\
\hline Aortic valve dysfunction $\mathrm{n}(\%)$ & I (3) \\
\hline Aortic dilatation $\mathrm{n}(\%)$ & $2(5)$ \\
\hline Structural abnormality n (\%) & $2(5)$ \\
\hline $\mathrm{LV}$ mass index, $\mathrm{g} / \mathrm{m}^{2}($ mean $\pm \mathrm{SD})$ & $74.7 \pm 16.6$ \\
\hline LA volume $/ \mathrm{BSA}, \mathrm{mL} / \mathrm{m}^{2}($ mean $\pm \mathrm{SD})$ & $24.3 \pm 6.9$ \\
\hline Aortic root diameter, mm (mean \pm SD) & $3.1 \pm 0.4$ \\
\hline Mitral dysfunction $\mathrm{n}(\%)$ & $8(20)$ \\
\hline Ejection fraction, \% (mean \pm SD) & $60.0 \pm 4.8$ \\
\hline Peak E velocity, $\mathrm{cm} / \mathrm{s}$ (mean $\pm \mathrm{SD}$ ) & $79.7 \pm 15.6$ \\
\hline Peak $A$ velocity, $\mathrm{cm} / \mathrm{s}$ (mean $\pm \mathrm{SD}$ ) & $60.3 \pm 13.4$ \\
\hline E/A ratio (mean $\pm S D)$ & $1.38 \pm 0.4$ \\
\hline Deceleration time, ms (mean \pm SD) & $191 \pm 33$ \\
\hline e' septal, $\mathrm{cm} / \mathrm{s}($ mean $\pm \mathrm{SD})$ & $9.9 \pm 2.4$ \\
\hline E/e' ratio (mean $\pm S D)$ & $7.5 \pm 1.7$ \\
\hline
\end{tabular}

Notes: *Statistically significant: $P<0.05$.

Abbreviations: ASDAS, Ankylosing Spondylitis Disease Activity Score; BASDAI, Bath Ankylosing Spondylitis Disease Activity Index; BASFI, Bath Ankylosing Spondylitis Functional Index; CRP, C-reactive protein; ESR, erythrocyte sedimentation rate; LV, left ventricular; NSAID, non-steroidal anti-inflammatory drug; TNF- $\alpha$, tumor necrosis factor alpha.

\section{Discussion}

Our observations suggest that TNF- $\alpha$ blocking therapy may favorably influence diastolic LV function in patients with an inflammatory disease. No differences were found in systolic LV function.

Increased diastolic LV dysfunction has previously been reported in AS, comparable to other diseases associated with an increased inflammatory response, such as rheumatoid
Table 2 Echocardiographic data

\begin{tabular}{|l|l|}
\hline Cardiac abnormalities & AS patients \\
\hline Cardiac abnormality $\mathrm{n}(\%)^{*}$ & $13(33)$ \\
\hline Systolic LV dysfunction $\mathrm{n}(\%)$ & $0(0)$ \\
\hline $\begin{array}{l}\text { Diastolic LV dysfunction } \mathrm{n}(\%) \\
\text { Grade I/II/III } \mathrm{n}(\%)\end{array}$ & $9(23)$ \\
\hline Aortic valve dysfunction $\mathrm{n}(\%)$ & $7(18) / 2(5) / 0(0)$ \\
\hline Aortic dilatation $\mathrm{n}(\%)$ & $\mathrm{I}(3)$ \\
\hline Structural abnormality $\mathrm{n}(\%)$ & $2(5)$ \\
\hline Other echocardiography variables & $2(5)$ \\
\hline LV mass index, g/m ${ }^{2}$ (mean \pm SD) & $74.7 \pm 16.6$ \\
\hline LA volume / BSA, mL/m ${ }^{2}$ (mean \pm SD) & $24.3 \pm 6.9$ \\
\hline Aortic root diameter, mm (mean \pm SD) & $3.1 \pm 0.4$ \\
\hline Mitral dysfunction $\mathrm{n}(\%)$ & $8(20)$ \\
\hline Ejection fraction, \% (mean \pm SD) & $60.0 \pm 4.8$ \\
\hline Diastolic LV function variables & \\
\hline Peak E velocity, cm/s (mean \pm SD) & $79.7 \pm 15.6$ \\
\hline Peak A velocity, cm/s (mean \pm SD) & $60.3 \pm 13.4$ \\
\hline E/A ratio (mean \pm SD) & $1.38 \pm 0.4$ \\
\hline Deceleration time, ms (mean \pm SD) & $191 \pm 33$ \\
\hline e' septal, cm/s (mean \pm SD) & $9.9 \pm 2.4$ \\
\hline E/e' ratio (mean \pm SD) & $7.5 \pm 1.7$ \\
\hline
\end{tabular}

Notes: *Statistically significant: $P<0.05$, One AS patient and one control had two abnormalities.

Abbreviations: AS, ankylosing spondylitis; BSA, body surface area; LA, left atrium; LV, left ventricular; $n$, number.

arthritis, psoriatic arthritis and diabetes mellitus. ${ }^{21-24}$ There is a growing interest in diastolic LV dysfunction as it has been shown to be an increasing problem with its own morbidity and mortality. ${ }^{25,26}$ Diastolic LV dysfunction is poorly understood and the pathophysiology of the disease is speculative at best. $^{15,27}$ Treatment of diastolic LV dysfunction is subject of many studies, all failing to bring improvement. ${ }^{28}$ Therefore, the present study might attribute to the understanding of this disease and help formulate new points of intervention in order to resolve this growing problem.

Pathogenically, the systemic inflammatory process may cause cardiac fibrosis, subsequently decreasing overall cardiac muscle elasticity and the relaxing abilities. ${ }^{27}$ In this study, inflammation levels were not significantly different in patients with diastolic LV dysfunction compared to those without. An effect of inflammation can, however, not be disregarded, as it is possible that the cumulative disease and inflammatory burden over several years affects the CV system, which is difficult to establish. Also, the investigated groups might have been too small to detect subtle differences. Patients with diastolic LV dysfunction were older and had a higher blood pressure compared to those without diastolic LV dysfunction, both known risk factors for the development of diastolic LV dysfunction. ${ }^{16}$ The prevalence of hypertension is often reported higher in AS compared to controls. ${ }^{29-31}$ The 
Table 3 Differences in characteristics of study population between AS patients with and without diastolic LV dysfunction at baseline

\begin{tabular}{|c|c|c|c|}
\hline Variables & $\begin{array}{l}\text { Normal diastolic LV } \\
\text { function }(n=3 I)\end{array}$ & $\begin{array}{l}\text { Diastolic LV } \\
\text { dysfunction }(n=9)\end{array}$ & $P$-value \\
\hline Age, years (mean $\pm S D)$ & $38.7 \pm 9.8$ & $52.2 \pm 7.2$ & $<0.001 *$ \\
\hline Years since diagnosis (median, range) & $8.0(2.0-13.0)$ & $8.0(2.0-19.0)$ & 0.649 \\
\hline HLA-B27 positive n (\%) & $26(84)$ & $7(78)$ & 0.645 \\
\hline CRP, mg/L (median, range) & $4(1-12)$ & $9(6-20)$ & 0.132 \\
\hline ESR, mm/h (median, range) & $6(5-25)$ & $14(6-46)$ & 0.292 \\
\hline $\mathrm{SBP}, \mathrm{mmHg}($ mean $\pm \mathrm{SD})$ & $124 \pm 13$ & $130 \pm 10$ & 0.190 \\
\hline $\mathrm{DBP}, \mathrm{mmHg}($ mean $\pm \mathrm{SD})$ & $80 \pm 7$ & $83 \pm 2$ & 0.256 \\
\hline Hypertension n (\%) & $2(6)$ & $4(44)$ & $0.002 *$ \\
\hline Prior anti TNF- $\alpha$ medication use $\mathrm{n}(\%)$ & $18(58)$ & $4(44)$ & 0.705 \\
\hline NSAIDs usage $\mathrm{n}(\%)$ & $25(8 \mathrm{I})$ & $8(88)$ & 1.000 \\
\hline BASDAI (mean \pm SD) & $5.7 \pm 1.8$ & $5.1 \pm 1.6$ & 0.761 \\
\hline ASDAS (mean \pm SD) & $3.2 \pm 1.2$ & $3.3 \pm 1.0$ & 0.405 \\
\hline
\end{tabular}

Note: *Statistically significant: $P<0.05$.

Abbreviations: ASDAS, Ankylosing Spondylitis Disease Activity Score; BASDAI, Bath Ankylosing Spondylitis Disease Activity Index; CRP, C-reactive protein; DBP, diastolic blood pressure; ESR, erythrocyte sedimentation rate; LV, left ventricular; NSAID, non-steroidal anti-inflammatory drug; SBP, systolic blood pressure; TNF, tumor necrosis factor.

Table 4 Effects of TNF- $\alpha$ blocking therapy

\begin{tabular}{|c|c|c|c|}
\hline Disease variables & Baseline & One year & $P$-value \\
\hline CRP, mg/L (median, range) & $5.0(2.0-12.0)$ & $2.0(1.9-3.2)$ & $<0.001$ \\
\hline ESR, $\mathrm{mm} / \mathrm{h}$ (median, range) & $10.0(6.0-22.0)$ & $4.0(2.0-7.0)$ & $<0.001$ \\
\hline BASDAI (mean \pm SD) & $5.2 \pm 1.6$ & $3.7 \pm 2.3$ & 0.001 \\
\hline ASDAS (mean \pm SD) & $3.1 \pm 1.2$ & $2.0 \pm 1.0$ & $<0.001$ \\
\hline $\mathrm{SBP}, \mathrm{mmHg}($ mean $\pm \mathrm{SD})$ & $127 \pm 13$ & $124 \pm 11$ & 0.095 \\
\hline $\mathrm{DBP}, \mathrm{mmHg}($ mean $\pm \mathrm{SD})$ & $82 \pm 7$ & $83 \pm 8$ & 0.472 \\
\hline \multicolumn{4}{|l|}{ Echocardiographic variables } \\
\hline $\mathrm{LV}$ mass index, $\mathrm{g} / \mathrm{m}^{2}($ mean $\pm \mathrm{SD})$ & $75.1 \pm 17.7$ & $73.1 \pm 15.0$ & 0.389 \\
\hline LA volume / BSA, $\mathrm{mL} / \mathrm{m}^{2}($ mean $\pm \mathrm{SD})$ & $24.4 \pm 6.8$ & $25.8 \pm 7.8$ & 0.384 \\
\hline Ejection fraction, \% (mean \pm SD) & $60.4 \pm 4.5$ & $58.8 \pm 4.7$ & 0.081 \\
\hline LVEDVI (mean \pm SD) & $65.1 \pm 13.4$ & $64.1 \pm 12.1$ & 0.313 \\
\hline LVESVI (mean \pm SD) & $26.2 \pm 7.2$ & $27.1 \pm 6.3$ & 0.966 \\
\hline Systolic LV dysfunction $\mathrm{n}(\%)$ & $0(0)$ & $0(0)$ & $\mathrm{N} / \mathrm{A}$ \\
\hline Diastolic LV dysfunction $\mathrm{n}(\%)$ & $6(20)$ & $2(6)$ & 0.125 \\
\hline Grade I/II/III n (\%) & $4(13) / 2(5) / 0(0)$ & $\mathrm{I}(3) / \mathrm{I}(3) / 0(0)$ & \\
\hline E/A ratio $($ mean $\pm S D)$ & $1.42 \pm 0.37$ & $1.42 \pm 0.46$ & 0.923 \\
\hline Deceleration time, $\mathrm{ms}($ mean $\pm \mathrm{SD})$ & $192 \pm 32$ & $198 \pm 28$ & 0.415 \\
\hline E/e' ratio (mean $\pm S D)$ & $7.7 \pm 1.8$ & $7.2 \pm 1.2$ & 0.104 \\
\hline
\end{tabular}

Abbreviations: AS, ankylosing spondylitis; ASDAS, Ankylosing Spondylitis Disease Activity Score; BASDAI, Bath Ankylosing Spondylitis Disease Activity Index; BSA, body surface area; CRP, C-reactive protein; ESR, erythrocyte sedimentation rate; LA, left atrial; LV, left ventricular; LVEDVI, left ventricular end-diastolic volume index; LVESVI, left ventricular end-systolic volume index; N/A, not applicable; $n$, number; TNF- $\alpha$, tumor necrosis factor alpha.

frequent use of NSAIDs, being the cornerstone of AS treatment, might add to this risk through its anti-natriuretic and vasoconstrictor effects. ${ }^{32}$ Blood pressure should therefore be monitored regularly in all AS patients and properly treated when necessary.

The development of TNF- $\alpha$ blockers has led to great improvements in the treatment of AS, with major reductions in disease and inflammatory activity. ${ }^{33}$ In this study, we found a potential favorable effect of TNF- $\alpha$ blocking treatment on diastolic LV function, as diastolic LV function normalized in four AS patients during treatment. This potential positive effect may be explained in several ways. First, suppressing inflammation (ie, TNF- $\alpha$ ) might lead to improvements in endothelial function through increases in nitric oxide production and a decrease in resting tension in the adjacent cardiomyocytes..$^{27,34-36}$ Second, lowering of disease activity may lead to improvements in physical capabilities and exercise possibilities resulting in better diastolic cardiac 


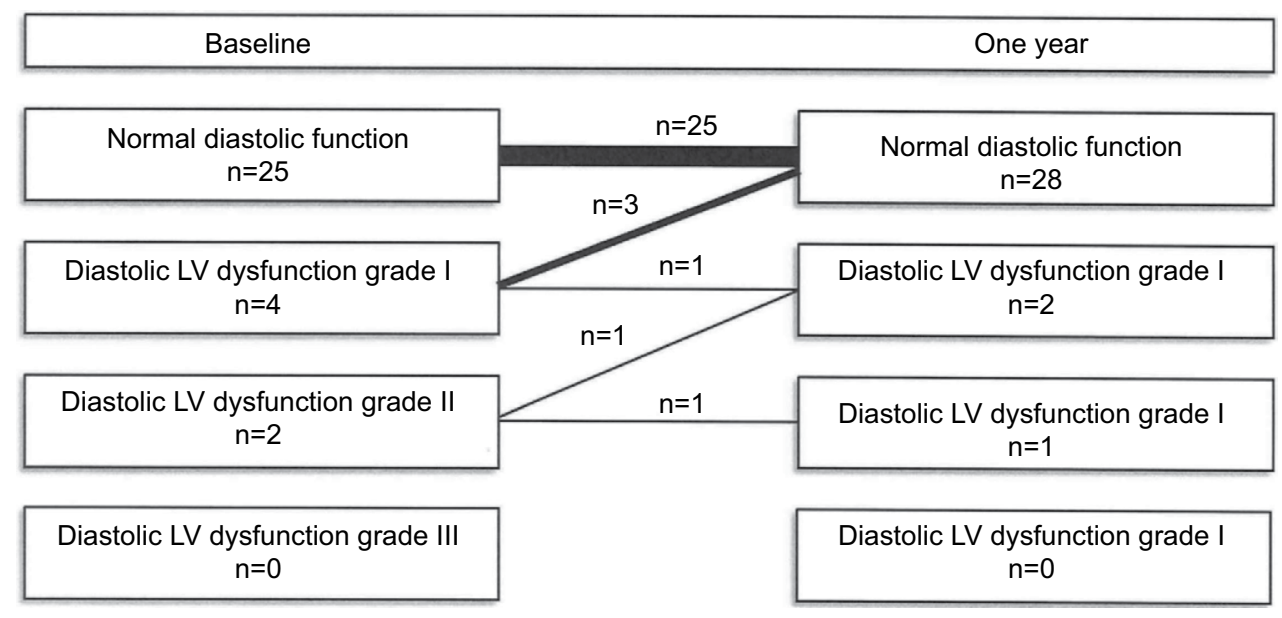

Figure 2 The effect of golimumab treatment on diastolic left ventricular function.

function. ${ }^{37,38}$ Third, decreased use of NSAIDs might positively affect blood pressure levels and lower the cardiac afterload, improving diastolic LV dysfunction.

This study has several strengths and limitations. First we included a homogeneous group of consecutive AS patients with high disease activity. Second, this is one of the first studies investigating the effects of TNF- $\alpha$ blocking therapy on LV function in AS. A limitation of this study is the relatively low number of included patients, which limits the possibility of detecting associations between cardiac pathology and disease characteristics such as inflammation.

Treatment with TNF- $\alpha$ blocking therapy showed a potential favorable effect on diastolic LV dysfunction, but the precise effect of TNF- $\alpha$ blocking treatment and the exact prevalence of cardiac pathology in AS remain to be determined in future studies.

\section{Data sharing statement}

The authors have access to raw data for this study and may be contacted for inquiries. According to national data protection rules, these linked raw data cannot be distributed further.

\section{Acknowledgment}

This is an investigator-initiated study partly financed by an unrestricted grant from Merck Sharp \& Dohme, the Netherlands.

\section{Author contributions}

All authors contributed to data analysis, drafting and revising the article, gave final approval of the version to be published, and agree to be accountable for all aspects of the work.

\section{Disclosure}

The authors report no conflicts of interest in this work.

\section{References}

1. Braun J, Sieper J. Ankylosing spondylitis. Lancet. 2007;369:1379-1390.

2. Ramiro S, van der Heijde D, van Tubergen A, et al. Higher disease activity leads to more structural damage in the spine in ankylosing spondylitis: 12-year longitudinal data from the OASIS cohort. Ann Rheum Dis. 2014;73(8):1455-1461.

3. El Maghraoui A. Extra-articular manifestations of ankylosing spondylitis: prevalence, characteristics and therapeutic implications. Eur $J$ Intern Med. 2011;22(6):554-560.

4. Nurmohamed MT, van der Horst-Bruinsma I, Maksymowych WP. Cardiovascular and cerebrovascular diseases in ankylosing spondylitis: current insights. Curr Rheumatol Rep. 2012;14(5):415-421.

5. Peters MJ, van der Horst-Bruinsma IE, Dijkmans BA, Nurmohamed MT. Cardiovascular risk profile of patients with spondylarthropathies, particularly ankylosing spondylitis and psoriatic arthritis. Semin Arthritis Rheum. 2004;34(3):585-592.

6. Dik VK, Peters MJ, Dijkmans PA, et al. The relationship between disease-related characteristics and conduction disturbances in ankylosing spondylitis. Scand J Rheumatol. 2010;39(1):38-41.

7. Klingberg E, Sveälv BG, Täng MS, Bech-Hanssen O, Forsblad-D'Elia $\mathrm{H}$, Bergfeldt L. Aortic Regurgitation Is Common in Ankylosing Spondylitis: Time for Routine Echocardiography Evaluation? Am J Med. 2015;128(11):1244-1250.

8. Heslinga SC, van Dongen CJ, Konings TC, et al. Diastolic left ventricular dysfunction in ankylosing spondylitis--a systematic review and metaanalysis. Semin Arthritis Rheum. 2014;44(1):14-19.

9. Forsblad-D'Elia H, Wallberg H, Klingberg E, Carlsten H, Bergfeldt L. Cardiac conduction system abnormalities in ankylosing spondylitis: a cross-sectional study. BMC Musculoskelet Disord. 2013; 14:237.

10. Lange U, Stapfer G, Ditting T, et al. Pathologic alterations of the heart and the kidney in patients with ankylosing spondylitis. Eur J Med Res. 2007;12(12):573-581.

11. Bulkley BH, Roberts WC. Ankylosing spondylitis and aortic regurgitation. Description of the characteristic cardiovascular lesion from study of eight necropsy patients. Circulation. 1973;48(5):1014-1027.

12. Haroon NN, Paterson JM, Li P, Inman RD, Haroon N. Patients With Ankylosing Spondylitis Have Increased Cardiovascular and Cerebrovascular Mortality: A Population-Based Study. Ann Intern Med. 2015;163(6): 409-416. 
13. Szabo SM, Levy AR, Rao SR, et al. Increased risk of cardiovascular and cerebrovascular diseases in individuals with ankylosing spondylitis: a population-based study. Arthritis Rheum. 2011;63(11):3294-3304.

14. Peters MJ, van Eijk IC, Smulders YM, et al. Signs of accelerated preclinical atherosclerosis in patients with ankylosing spondylitis. J Rheumatol. 2010;37(1):161-166.

15. Zile MR, Brutsaert DL. New concepts in diastolic dysfunction and diastolic heart failure: Part II: causal mechanisms and treatment. Circulation. 2002;105(12):1503-1508.

16. Chatterjee K, Massie B. Systolic and diastolic heart failure: differences and similarities. J Card Fail. 2007;13(7):569-576.

17. van der Linden S, Valkenburg HA, Cats A. Evaluation of diagnostic criteria for ankylosing spondylitis. A proposal for modification of the New York criteria. Arthritis Rheum. 1984;27(4):361-368.

18. Lang RM, Badano LP, Mor-Avi V, et al. Recommendations for cardiac chamber quantification by echocardiography in adults: an update from the American Society of Echocardiography and the European Association of Cardiovascular Imaging. J Am Soc Echocardiogr. 2015;28(1):1-39.

19. Nagueh SF, Appleton CP, Gillebert TC, et al. Recommendations for the evaluation of left ventricular diastolic function by echocardiography. J Am Soc Echocardiogr. 2009;22(2):107-133.

20. Vahanian A, Alfieri O, Andreotti F, Antunes MJ, Baron-Esquivias G, Baumgartner $H$. Guidelines on the management of valvular heart disease (version 2012). Eur Heart J. 2012;33:2451-2496.

21. Aslam F, Bandeali SJ, Khan NA, Alam M. Diastolic dysfunction in rheumatoid arthritis: a meta-analysis and systematic review. Arthritis Care Res. 2013;65(4):534-543.

22. Shang Q, Tam LS, Yip GW, et al. High prevalence of subclinical left ventricular dysfunction in patients with psoriatic arthritis. J Rheumatol. 2011;38(7):1363-1370.

23. Levelt E, Mahmod M, Piechnik SK, et al. Relationship Between Left Ventricular Structural and Metabolic Remodeling in Type 2 Diabetes. Diabetes. 2016;65(1):44-52.

24. Seferović PM, Paulus WJ. Clinical diabetic cardiomyopathy: a twofaced disease with restrictive and dilated phenotypes. Eur Heart J. 2015;36(27):1718-1727.

25. Aljaroudi W, Alraies MC, Halley C, et al. Impact of progression of diastolic dysfunction on mortality in patients with normal ejection fraction. Circulation. 2012;125(6):782-788.

26. Halley CM, Houghtaling PL, Khalil MK, Thomas JD, Jaber WA Mortality rate in patients with diastolic dysfunction and normal systolic function. Arch Intern Med. 2011;171(12):1082-1087.
27. Paulus WJ, Tschöpe C. A novel paradigm for heart failure with preserved ejection fraction: comorbidities drive myocardial dysfunction and remodeling through coronary microvascular endothelial inflammation. J Am Coll Cardiol. 2013;62(4):263-271.

28. Massie BM, Carson PE, Mcmurray JJ, et al. Irbesartan in patients with heart failure and preserved ejection fraction. $N$ Engl J Med. 2008;359(23):2456-2467.

29. Chou $\mathrm{CH}$, Lin MC, Peng CL, et al. A nationwide population-based retrospective cohort study: increased risk of acute coronary syndrome in patients with ankylosing spondylitis. Scand J Rheumatol. 2014;43(2):132-136.

30. Peters MJ, van Halm VP, Voskuyl AE, et al. Does rheumatoid arthritis equal diabetes mellitus as an independent risk factor for cardiovascular disease? A prospective study. Arthritis Rheum. 2009;61(11): 1571-1579.

31. Han C, Robinson DW, Hackett MV, Paramore LC, Fraeman KH, Bala MV. Cardiovascular disease and risk factors in patients with rheumatoid arthritis, psoriatic arthritis, and ankylosing spondylitis. J Rheumatol. 2006;33(11):2167-2172.

32. White WB. Cardiovascular effects of the selective cyclooxygenase-2 inhibitors. Subcell Biochem. 2007;42:145-158.

33. Maxwell LJ, Zochling J, Boonen A. TNF-alpha inhibitors for ankylosing spondylitis. Cochrane Database Syst Rev. 2015;4:CD005468.

34. Putko BN, Wang Z, Lo J, et al. Circulating levels of tumor necrosis factor-alpha receptor 2 are increased in heart failure with preserved ejection fraction relative to heart failure with reduced ejection fraction: evidence for a divergence in pathophysiology. PLoS One. 2014;9(6):e99495.

35. van Eijk IC, Peters MJ, Serné EH, et al. Microvascular function is impaired in ankylosing spondylitis and improves after tumour necrosis factor alpha blockade. Ann Rheum Dis. 2009;68(3):362-366.

36. Sari I, Okan T, Akar S, et al. Impaired endothelial function in patients with ankylosing spondylitis. Rheumatology. 2006;45(3):283-286.

37. Edelmann F, Gelbrich G, Düngen HD, et al. Exercise training improves exercise capacity and diastolic function in patients with heart failure with preserved ejection fraction: results of the Ex-DHF (Exercise training in Diastolic Heart Failure) pilot study. J Am Coll Cardiol. 2011;58(17):1780-1791.

38. Brassard P, Legault S, Garneau C, Bogaty P, Dumesnil JG, Poirier P. Normalization of diastolic dysfunction in type 2 diabetics after exercise training. Med Sci Sports Exerc. 2007;39(11):1896-1901.
Biologics: Targets and Therapy

\section{Publish your work in this journal}

Biologics: Targets and Therapy is an international, peer-reviewed journal focusing on the patho-physiological rationale for and clinical application of Biologic agents in the management of autoimmune diseases, cancers or other pathologies where a molecular target can be identified. This journal is indexed on PubMed Central, EMBase, and Scopus.
Dovepress

The manuscript management system is completely online and includes a very quick and fair peer-review system, which is all easy to use. Visit http://www.dovepress.com/testimonials.php to read real quotes from published authors. 